\title{
CURRENT DEVELOPMENT SITUATION OF MARINE ECONOMY IN QUANG BINH PROVINCE
}

\author{
Hoang Phan Hai Yen ${ }^{1}$
}

\begin{abstract}
Marine development trend with a new economic mindset is being paid great attention by many countries in the world in order to solve socio-economic development issues for present and future. Quang Binh is one of the 28 marine provinces and cities of Vietnam with the highest marine influence index in the country. The determination of marine economy as a key development direction in recent years has made Quang Binh a fairly good province with many socio-economic criteria achieving and increasing the set targets. The paper analyzes the current situation of marine economic development, thereby proposing solutions to promote marine economic development of Quang Binh province in the future.
\end{abstract}

Keywords: Economy, marine economy, coastal economy, coastal areas of Quang Binh Province.

Received: December 11, 2019 Accepted: December 12, 2019 Published on: December 20, 2019

\section{Introduction}

The world's seas and oceans cover $71 \%$ of the Earth's surface. Marine potential is much greater than mainland's one but due to its environmental characteristics, the exploitation and use of marine resource is still limited. Since ancient times, mankind has used the sea for various purposes for life. Terms "marine economy" is derived from human activities of marine exploration. Today, the marine economy is a group of important economic sectors in the world economy, especially for the marine countries, it has strategic roles.

Marine economy is narrowly construed as all economic activities taking place on the sea, mainly including: Maritime economy (shipping and port services); seafood (fishing and aquaculture); offshore oil and gas exploitation; sea travel; salt making; marine search and rescue services; island economy. Marine economy is broadly construed as economic activities directly related to marine exploitation; although they do not take place on sea, these economic activities

${ }^{1}$ Department of Geography, School of Social Education, Vinh University

Email: hoangphanhaiyen@vinhuni.edu.vn depend on sea elements or directly serve marine economic activities in the coastal zones, for examples ship building and repairing, oil and gas processing research, seafood processing industry, marine services, marine communication, marine science and technology, human resources training for marine economic management, and basic surveys on marine environmental resources.

Marine economy has developed since the 15 th century, in the association with the geographical discovery in Europe. Today, marine economic studies direction:

- General research on coastal areas, typically the work of GoB (2005), EUCC (2007) [5]. The authors focused on the study of the characteristics and functions of coastal areas (including emphasis on socio-economic activities in the seas and resource competitions among regions), issues of coastal areas (environmental pollution, resource degradation, natural disasters, environmental incidents, climate change and sea level rise, etc.). 
- Researching on socio-economic activities in coastal areas, typically the work of BMVBS and BBR (2006) [3]. In this research, specific economic sectors of the coastal strip are also mentioned.

- Research direction on the coastal environment, typically Ando et al. (2004) [2]. Such studies shows that the coastal environment is a unified whole. Pollution of each environmental component leads to influence on others. Among these, the water environment has the greatest impact on other environmental components.

In Vietnam, the role and importance of the marine economy has been defined clearly, so in recent decades, there have been many researches on the marine and island economy mainly on two main directions. i.e. Study on potentials, general assessments of natural conditions and natural resources in service of the general planning and development of socio-economic development in coastal and islands economy; Study on coastal and marine environment and impacts of climate change (CC) on coastal environment.

Vietnam has 28/63 provinces and cities directly under the central government with beaches, with 125 coastal districts and 12 islands, accounting for $42 \%$ of national land area and $45 \%$ of national population [1].

Quang Binh is a coastal province with 116.04 $\mathrm{km}$ long coastline and 20,000 km2 wide sea area 2 and 6 coastal districts and cities. In recent years, marine economic sectors have contributed a significant proportion in the production value of economic sectors, the export value of the province, creating jobs for many workers, creating a significant change in quality of life of people ... However, Quang Binh's marine economy is still featured with small exploitation. It has not promoted and fully awakened its marine potentials and strengths to serve the process of economic, social development and security defense; There has not had comprehensive policy system to promote the rapid, effective and sustainable development of the marine economy; the level of economic linkages between coastal districts and cities in Quang Binh province is not close human life in local coastal are still difficult, etc.

\section{Materials and Methods}

\subsection{Data collection}

The data is calculated and analyzed from sources such as: Statistical Yearbook of Quang Binh Statistical Office, reports of People's Committee of Quang Binh province, Department of Agriculture and Rural Development of Quang Binh Province, Department of Tourism of Quang Binh Province, People's Committees of coastal districts and towns in Quang Binh province. Primary data are collected and then processed, calculated and summarized into tables for comparison, comment and analysis. All data in the period of 2010-2018 are collected and survey results are conducted in 2019.

\subsection{Methodology}

The paper combined following methods such as: Data collection, analysis, synthesis and comparison. In particular, the author uses two main methods:

- Field survey: in order to obtain necessary information, apart from the collected primary materials and data, field survey provides many practical knowledge and documents which diversifies and supplement the content of the problem. This is also a typical and indispensable method in geography research, especially socioeconomic geographic research. Within the scope of the paper, the author conducted the field work, observed, described and recorded the development of marine economic sectors and fields in some communes and wards under Quang Binh coastal districts, towns and cities such as Hai Thanh ward, Dong My ward, Quang Phu commune, Bao Ninh commune (Dong Hoi city), Nhan Trach commune (Bo Trach district).

- Managerial consultation: These were oral interviews with chairmen of People's Committee of districts, towns, cities with beach, heads of agriculture division, heads of agricultural exten- 
sion stations, heads of labor, war invalids and social affairs offices of districts, towns and cities bordering the sea. The total number of interviewed managers is 10 . The interview content is mainly related to: Strategies and policies for marine economy development, challenges for marine economy development and current and future CBT development solutions.

\section{Results and Discussion}

\subsection{The main advantages of Quang Binh} province in marine economy development

Quang Binh is a coastal province with a coastline of $116.04 \mathrm{~km}$, territorial sea of 20,000 $\mathrm{km}^{2}$ with 6 coastal districts, towns and cities, namely Dong Hoi City, Ba Don Town, Quang Trach District, Bo Trach District, Quang Ninh and Le Thuy district. The total natural area of the territorial sea is $5,502 \mathrm{~km}^{2}$ the population in 2017 is 751,767 people, the average population density is 337 people $/ \mathrm{km}^{2}$, accounting for $68.2 \%$ of the provincial area and $85.2 \%$ of the provincial population. In particular, there is a large workforce (accounting for $63 \%$ of the coastal population), which is young, healthy, industrious, hard-working. They are important labor reserver for the development of the marine economy which have to be employed and used effectively.

It is considered that territorial sea of Quang Binh province has large reserves of seafood which are diverse and rich in species. It is estimated to have over 1,000 species, including rare species such as lobster, shrimp, black tiger, squid, cuttlefish, cockle, sea snake, etc. These seafood species are high economic value but other provinces have litte or have not got. In the current context, the aquaculture households in Quang Binh are able to develop the salty and brackish aquaculture industry. The potential water surface area for salt and brackish aquaculture in Quang Binh province is about 4,000 ha.

With regards to ecosystems, Quang Binh has white coral reefs with an area of up to tens of hectares. They are not only a source of fine art materials with high economic value, but also create conditions to maintain and develop the typical flora of the deep sea in the Central region of Vietnam. According to the survey and assessment data of the Directorate of Fisheries, the fish reserve in Quang Binh territorial sea is about 51,000 tons. In addition, some species such as tuna, flying fish, and the estimated shrimp reserve is 2,000 tons and squid is 8,000 to 10,000 tons.

With a long coastline and $20,000 \mathrm{~km}^{2}$ of continental shelf, two large estuaries, Quang Binh province is capable of developing into a largescale seaport such as Nhat Le and Gianh seaports. In the near future, these seaports will be a place to trade and connect major tourist centers among the North Central of Vietnam, Vietnam with Asean regions. In addition, Quang Binh province contain a diverse and unique tourism potential. Apart from Phong Nha - Ke Bang National Park, which has been recognized as a world natural heritage by UNESCO? Quang Binh has a system of beautiful beaches like Nhat Le beach, Da Nhay beach, Bao Ninh beach, and spiritual tourism places like Vung Chua - Dao Yen. Therefore, Quang Binh has increasingly attracted more tourists to visit and relax.

\subsection{Current development situation of ma-} rine economics in Quang Binh

a. Fisheries and exploration of aquatic products

The fishing capacity has been increasingly enhanced, in the period of 2013 - 2017, the number of motorized ships and boats increased rapidly. The total number of motorized boats increased from 4,346 units in 2013 to 5,443 units in 2017 (an average growth of 4.6\% /year). Among these, from 2013 to 2015 the number of boats decreased sharply, but then increased from 2016 - 2017. The number of boats in 2017 increased 743 units compared to the former plan and it mainly included boats operating in coastal areas (581 units). The enhancement of fishing capacity has brought about results in terms of 
fishing capacity as well as economic values achieved by the fishing industry.

Table 1. Fishing production in Quang Binh province in the period of 2013 - 2017 [4,7]

\begin{tabular}{cccccccc}
\hline No & List & Unit & $\mathbf{2 0 1 3}$ & $\mathbf{2 0 1 4}$ & $\mathbf{2 0 1 5}$ & $\mathbf{2 0 1 6}$ & $\mathbf{2 0 1 7}$ \\
\hline 1 & Fishery production & Ton & 38,321 & 50,483 & 54,007 & 46,732 & 55,823 \\
2 & Production value & Billion & 954 & 1,298 & 1,444 & 1,269 & 1,520 \\
& & dong & & & & & \\
\hline
\end{tabular}

\section{b. Salty brackish aquaculture}

In the period of 2013 - 2017, the salty brackish aquaculture area tended to increase slightly with an annual growth rate of $1.7 \%$ from 1,274 ha in 2013 to 1,435 ha in 2017. Thus, compared with the general growth rate of aquaculture in the whole province $(3.3 \%)$, the salty brackish water aquaculture area increases more slowly.

The brackish aquaculture area decreased from $27 \%$ in 2013 to $24.2 \%$ of the total aquaculture area because aquaculture zones were recovered for economic and tourism development such as in Hai Ninh commune - Quang Ninh (30 ha of sand ponds), Phu Hai - Dong Hoi ward (about 40 ha of earthen ponds), etc. The locality with the largest area growth rate is Le Thuy district, $15.9 \%$ / year. Aquaculture area in Dong Hoi city decreased by $4.7 \% / y e a r$ due to land recovery for urbanization, economic development and tourism.

Table 2. Brackish and saltwater aquaculture area by locality distribution in Quang Binh province in the period of 2013 - 2017 [4,7]

(Unit: ha)

\begin{tabular}{ccccccc}
\hline No. & District & $\mathbf{2 0 1 3}$ & $\mathbf{2 0 1 4}$ & $\mathbf{2 0 1 5}$ & $\mathbf{2 0 1 6}$ & $\mathbf{2 0 1 7}$ \\
\hline 1 & Le Thuy & 26 & 46 & 43 & 43 & 73 \\
2 & Quang Ninh & 124 & 120 & 120 & 131 & 154 \\
3 & Dong Hoi & 130 & 81 & 83 & 80 & 93 \\
4 & Bo Trach & 522 & 488 & 536 & 516 & 704 \\
5 & Ba Don & 386 & 360 & 347 & 345 & 324 \\
6 & Quang Trach & 86 & 86 & 86 & 79 & 88 \\
& Total province & 1,274 & 1,181 & 1,215 & 1,194 & 1,435 \\
$\quad$ area & & & & & \\
\hline
\end{tabular}

Aquaculture area of vannamei accounted for $60.2 \%$, of tiger shrimp accounted for $26.7 \%$, of sea crab accounted for $20.5 \%$ of salty brackish water aquaculture area, the rest is for fish and some aquatic species.

Methods of brackish water aquaculture include brackish water aquaculture in earthen ponds, in water pond liners on coastal sand and in water cages. Brackish water aquaculture in earthen ponds, a common practice, increased from 953 ha in 2013 to 1,200 ha in 2017 (average rate of $3.3 \% / y e a r)$, ponds and lakes are mainly concentrated in Quang Ninh, Bo Trach district... Aquaculture in sand-lined ponds decreased from 321 ha in 2013 to 235 ha in 2017 (an average rate of $-4.36 \% /$ year). This is a new method that appeared in 2002 but the area decreased due sand pond recovery for the socioeconomic and tourism development. Brackish water cage culture, which is a new method of culture along the riverside such as Gianh river, Nhat Le river with seabass and persimmon, reached 957 cages in 2017.

\section{c. Seafood processing and trading}

- Source of raw materials for seafood processing: 
Raw materials for seafood processing, especially export processing, still mainly come from the natural exploitation. aw materials from aquaculture (mainly brackish water shrimp) are often unstable, seasonal and subject to strict food safety and hygiene inspection.

Aquaculture products have faced with strict EU inspection for the past decade because of shrimp disease (white spot disease, hepatopancreatic necrosis ...), which have been found to be contaminated with chemical residues, antibiotics, impurities pumping into shrimp ... in some provinces. This significantly affected the shrimp trading market.

In the structure of export seafood processing, frozen products tend to decrease over the years, from 2,447 tons in 2013 to 944 tons in 2017. Processing of fish sauce tends to increase, from 3,471 million liters in 2013 to 3,976 million liters in 2017 and the average growth rate is $1.96 \%$. Grilled fish increased from 3,100 tons in 2013 to 5,900 tons in 2017 , the average annual growth rate is $9.36 \%$.

Poor development of seafood processing results from outdated processing technology, limited business management and market experience. On the other hand, due to the fact that most of factories which were equitized and transferred to new investors did not have solutions for technological innovation, business and production reform and trade promotion. Therefore, their export processing was delayed and the majority of factories are not eligible for direct export, and production for only some processed goods and entrusted exports with low output. Seafood processing products are still undiversified.

The domestic processing has been promoted; the quality of dried seafood and fish sauce is guaranteed and well consumed domestically. The development of domestic production and processing has contributed to solving the output for fishing, creating jobs for fishermen and meeting the consumption needs of people inside and outside the province.

\subsubsection{Sea tourism}

\section{a. Tourist market}

The number of tourists to Quang Binh beach in the past 5 years has got relatively fast growth. The number of visitors increased from 943,840 in 2013 to 2,149,697in 2017 and, the average growth of the whole period reached $17.9 \%$ and equal to $65 \%$ of the total number of tourists to Quang Binh.

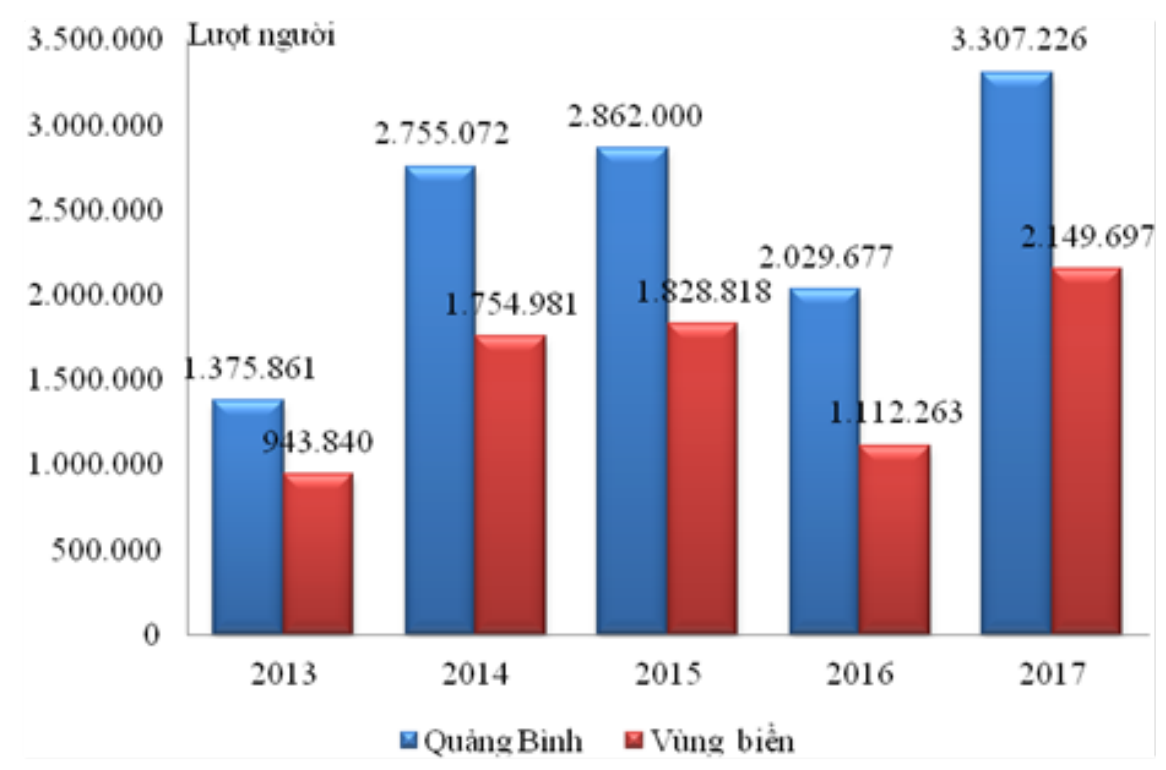

Fig. 1. Number of tourists to Quang Binh sea zone in the period of 2013 - 2017 [4,7] 
It can be seen that tourists to Quang Binh are mainly for sea tourism which always accounts for over $50 \%$ of the province's tourists. In general, the number of tourists to Quang Binh tends to increase but decreased in 2016. This situation is affected by many objective factors, mainly due to the marine environmental incident in 2016 that directly affected Quang Binh sea and thereby reducing the number of tourists to the sea. Moreover, the investment in developing tourism in many new tourist destinations makes tourists to Quang Binh not only for sea-bathing but also tourissm destinations in the province. Quang Binh sea tourism showed very good signs of recovery, the number of tourists increased 1.9 times in 2017 compared to that in 2016. As a result, the proportion of sea tourists rose up to $65 \%$ of the total number of tourists.

The number of tourists to Quang Binh terri- torial sea is differentiated. according to seasons: $70-80 \%$ of visitors come in the tourist season from May 1 to August 31, only 20-30\% come in off tourist season. Relaxation and swimming are popular in combination with visiting a number of cultural monuments and festivals, for example Vung Chua - Dao Yen, Canh Duong mural village, seasonal festival, fishing festival...

Regarding the structure of tourists to Quang Binh territorial sea, the majority of tourists are domestic tourists, accounting for over $97 \%$ of the total number of tourists. This percentage has almost no shift from 2013 to 2016, the amount of International visitors accounts for a very small percentage, about $2 \%$. This shows that the attraction of Quang Binh sea tourism to the world is too little and mainly still to domestic tourists.

\section{b. Sea tourism revenue}

Table 3. Sea tourism revenue in Quang Binh for the period of 2013 - 2017 [4,7]

\begin{tabular}{llccccc}
\hline & Unit & 2013 & 2014 & 2015 & 2016 & 2017 \\
\hline Quang Binh (1) & $\begin{array}{l}\text { Billion } \\
\text { dong }\end{array}$ & 1,376 & 3,031 & 3,148 & 2,273 & 3,737 \\
Marine area & $\begin{array}{l}\text { Billion } \\
\text { dong }\end{array}$ & 923 & 1,849 & 1,960 & 1,323 & 2,623 \\
Ratio 2/1 & $\%$ & 67.05 & 61.00 & 62.25 & 58.20 & 70.20 \\
\hline
\end{tabular}

In the period of 2013 - 2015, tourism sea tourism revenue increased rapidly and increased from 923 billion VND in 2013 (accounting for $67.05 \%$ of the total tourism revenue of the province) to 1,960 billion VND in 2015 which is 2.1 times higher than that in 2013 Although tourism revenue in 2016 decreased due to the impact of marine environment, the following years increased rapidly again, reaching 2,623 billion VND, accounting for $70.20 \%$ of tourism revenue of the whole province and an average growth of the whole period reached $23.2 \%$. Thus, compared to the growth rate of tourist arrivals, the increase in revenue is higher.

\subsubsection{Marine industry}

The province has a coastline of $116.04 \mathrm{~km}$ and territorial sea of about $20,000 \mathrm{~km}^{2}$ with 5 estuaries and important ports such as Nhat Le port, Gianh port, Hon La port, Thang Loi deep-water port in airtight location. It is very convenient for mooring and developing fishing logistics and shipping services. Among the four ports in Quang Binh, Hon La port has the largest cargo throughput (3,172,345 tons in 2017). Gianh Port has a small custom clearance capacity and throughput. Along with the seaport system development, shipping flows and shipping revenue also tends to increase. 


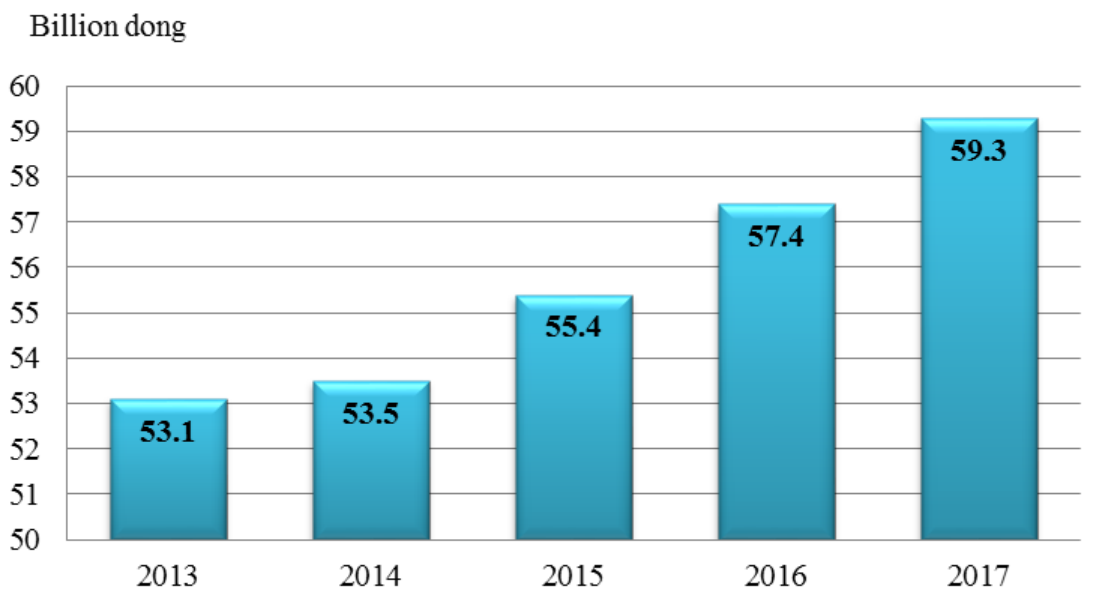

Fig. 2. Shipping revenue of Quang Binh in the period 2013 - 2017 (VND billion) [4]

Shipping revenue increased from VND 53.1 billion in 2013 to VND 59.3 billion in 2017, 1.1 times higher in the past 5 years but such a growth rate is still slow and not commensurate with the potential of sea transportation development. The contribution of sea transport to the overall revenue of the province's transport is $1.9 \%$, a very modest figure. Shipping revenue structure comes from $100 \%$ cargo shipping.

3.2.4. Marine minerals exploiting and processing

The territorial sea and islands of Quang Binh province have many precious minerals such as gold, iron, titanium, pyrite, lead, zinc and some other non-metallic minerals such as kaolin, quartz sand, limestone, granite...

Quartz sand in Quang Binh province has good quality compared to that in other regions in the country, so it is an advantage for Quang Binh province to develop high-quality glass industry to serve domestic demand and export to foreign countries. In the north, there are white sand beach with an area of nearly $40 \mathrm{~km}^{2}$ and estimated reserves of 35 million tons in Ba Don Quang Trach, and with reserves of 5 million tons in Thanh Khe - Bo Trach. The sand is high purity quartz, fine-sized, with $\mathrm{SiO}_{2}$ content of 98 $99 \%$. It is located next to roads, so it is easy to exploit and transport and can serve the production of high-class glass goods and materials from other silicate. In the period from 2013-2017, sand mining output tended to increase, from $1,593,674 \mathrm{~m}^{3}$ in 2013 to $1,664,542 \mathrm{~m}^{3}$ in 2017 , the average growth rate of the whole period was $1.87 \%$.

Regarding titanium exploitation, the provincial People's Committee has granted 6 titanium exploitation licenses to four companies located mainly in the key coastal sandy areas of Quang Trach and Le Thuy districts. Titanium exploitation activities are concentrated in Le Thuy and four companies have been licensed to exploit Titan with an area of about 150 ha but 3 companies have not exploited yet, including Thanh Binh Construction Company Limited, Sen Hong Company Limited, and Hoang Long Mineral Joint Stock Company. Particularly, Quang Binh Import-Export Joint Stock Company has been granted 100 hectares and has exploited 76 hectares. Titanium exploitation output in Quang Binh is still low and tends to decrease, from 43,360 tons in 2013 to 25,897 tons in 2017 with the average growth of $-12.1 \%$.

\subsubsection{Salt production}

Salt production of Quang Binh in 2013 reached 8,930 tons and tended to decrease, especially the direct impact of marine environmental incidents caused the sharp drop to 6,585 tons in 2016 and the output increased slightly in 207 but still not equal to the output of previous years. In the whole period, salt production decreased with the average growth of the whole period of $-4.4 \%$. The salt production decrease results from the narrowing of salt production area in Quang Binh. 
Table 4. Salt production in Quang Binh province (2013 - 2017) [4]

\begin{tabular}{llllll}
\hline & $\mathbf{2 0 1 3}$ & $\mathbf{2 0 1 4}$ & $\mathbf{2 0 1 5}$ & $\mathbf{2 0 1 6}$ & $\mathbf{2 0 1 7}$ \\
\hline Sea salt & 8,930 & 8,294 & 8,254 & 6,585 & 7,472 \\
\hline
\end{tabular}

Currently, salt production in Quang Binh is only maintained in Quang Phu commune (Quang Trach district). Quang Phu now has 74.81 ha of salt production land located mainly in 4 villages of Phu Loc 1,2,3,4 with 268 households and more than 600 laborers working in the field. With an average output of 100 tons/ 1 ha/season (with value of about 100-150 million VND), the average annual salt output of Quang Phu is about 6,000-7,500 tons, reaching a turnover of 9-11 billion VND.

\subsection{General assessment of the marine econ-} omy development in Quang Binh province

Over the past 5 years, Quang Binh has continued to take advantage of the potentials and advantages of its seas and coastal areas to develop marine economic sectors. The right policy line for marine economic development is suitable with the general situation of the province as well as with the international and domestic context, thereby created favorable conditions for the development of Quang Binh's marine industry with a quite diverse structure. Among these, seafood and marine tourism are the two main sectors. The development of marine economic sectors in recent years has great significance for the province's overall economy, especially marine economy.

However, this development is still not commensurate with the local potential and advantages; the contribution rate in the economy is generally small and there has had no cooperation among marine economic sectors yet.

Production capacity of fishing increases, but is mainly small-sized and manual. Investment capital for motor vehicle procurement with large capacity and technology is limited, so, they are unable to go to the sea for a long time. Splendid fishing grounds and high-density fishing boats lead to over-exploitation. The protection of marine resources has not been thoroughly imple- mented. Estuaries, creeks and fishing stakes have been exploited all year round, that has destroyed food sources for brackish and brackish aquaculture and many larvae of high value brackish water species. The fishing with mines has led to a significant reduction in the stock of some marine species. All labor forces have been free to do business and compete with each other, so state owned companies have operated ineffectively and are unable to adapt the market mechanism. Some production facilities have to be dissolved or merged.

The growth of marine tourism is not commensurate with the potential and available tourism resources; in term of sea tourism, the number of international tourists is small and the number of domestic tourists with low consumption capacity is predominant. Tourism business achieved low efficiency and small contribution to the province's GRDP; Quang Binh sea tourism development is seriously imbalanced, mainly focusing on developing accommodation business, but travel and transportation business and entertainment services are undeveloped. The market for tourists is still limited due to shortage of attractive tour or journey, and no linkage between tourism activities with traditional festivals, trade villages and tourism businesses. The sea tourism is also highly seasonal. Tourism products are poor and undiversified with low competitiveness. The operation of services is still small-sized, and fragmented. Although service quality has been improved, most of them are still at a low level compared to the normal level.

Maritime industry has developed weakly compared to the province's potential. The port and sea network operation efficiency is not high. Its competitiveness is lower than other means of transport. Among the seaports in Quang Binh, only Hon La port has a significant operating capacity, but its efficiency is not high. Infrastruc- 


\section{BÀI BÁO KHOA HỌC}

ture in the port has not been well invested; means of loading and unloading equipment, storage and transportation of cargo have not been modernized and developed synchronously.

\section{Conclusion}

Quang Binh's marine economy has gained important achievements in recent years. The contribution of marine economy in economic growth rate, foreign investment attraction, economic restructure, territorial space change ... of Quang Binh province is getting bigger and big- ger. However, in the development process, the marine economic sectors have not yet fully promoted their inherent potentials; there is a lack of a long-term Master Plan, no comprehensive system of policies to promote rapid, effective and sustainable economic development ... Therefore, it is required that the province must have strategies and steps in the right direction to further promote the internal and external advantages of marine economic sectors in the near future.

\section{References}

1. Nguyen, L.A., et al. (2011), Coastal Zone Integrated Management. Nha Trang University.

2. Ando, A.W., Khanna, M., Wildermuth, A., Vig, S., (2004), Natural Resource Damage Assessment: Methods and Cases. Illinois Waste Management and Research. Center (A Division of the Illinois Department of Natural Resources) One Hazelwood Dr. Champaign, IL 61820.

3. BMVBS and BBR (2006), ICZM: strategies for coastal and marine spatial planning, Research project of the Federal Ministry of Transport, Building and Urban Affairs (BMVBS) and Federal Office for Building and Spatial Planning (BBR).

4. Nghe An Statical Office (2018), Statistics Yearbook of Quang Binh province 2017. Statistics Publishing House.

5. GoB (2005), Coastal Zone Policy. Ministry of Water Resources, Government of the People's Republic of Bangladesh.

6. Quang Binh Provincial People's Committee (2017), Wrap-up report on implementation of the plan 2017 and plan for eco-social development of 2018. Quang Binh.

7. Quang Binh Provincial People's Committee (2018), Plan No. 778/KH-UBND on implementing the Target program "Sustainable aquatic product economy development in the period of 20182020”, Quang Binh. 